\title{
Pedagodzy społeczni
}

\section{jako współtowarzysze migrantów w procesie adaptacji społeczno-kulturowej, integracji i inkluzji}

\section{KEYWORDS}

social pedagogue, migrations, discourse, integration, inclusion

\begin{abstract}
Marta Pietrusińska, Pedagodzy społeczni jako współtowarzysze migrantów w procesie adaptacji społeczno-kulturowej, integracji i inkluzji [Social pedagogues as migrants companions in socio-cultural adaptation, integration and inclusion]. Kultura - Społeczeństwo - Edukacja nr 2(18) 2020, Poznań 2020, pp. 251-262, Adam Mickiewicz University Press. ISSN 2300-0422. DOI 10.14746/ kse.2020.18.10.1.

Increased migration to Poland and at the same time an increase in anti-immigrant attitudes cause that social pedagoguesface a new challenge related to the integration and inclusion of migrants. In the article I focus on a transformation of social pedagogues roles due to the mentioned above social changes and new challenges - the discourse the introduces symbolic violence, learned helplessness and lack of agency of migrants, and the insufficient number of social pedagogues with intercultural and andragogical competence. Based on these difficulties faced by social pedagogues I describe what could be their role in the process of integration of migrants and the host society.
\end{abstract}

\section{Nowe trendy w migracjach do Polski}

W 2016 roku, po raz pierwszy od dziesięcioleci, Polska stała się krajem o dodatnim saldzie migracyjnym, co oznacza, że więcej osób przyjeżdża do kraju, niż go opuszcza (Czakon-Tralski, Kłóska, 2018). Jest to niewątpliwie ważna kwestia spo-

\footnotetext{
* ORCID: 0000-0002-1248-6816.
} 
łeczna stawiająca przed polskim społeczeństwem nowe wyzwania, chociaż migracje zewnętrzne nie są nowym zjawiskiem w Polsce. Od lat dziewięćdziesiątych polską strategię migracyjną kształtowała polityka międzynarodowa, głównie polityka migracyjna Unii Europejskiej (Łazor, 2016), dlatego w dyskursie publicznym udało się stworzyć wizję otwartego, integracyjnego społeczeństwa, w którym migranci są postrzegani jako element wzbogacający. Rok 2015 przyniósł jednak znaczną narracyjną zmianę spowodowaną paniką moralną, która była rezultatem tzw. kryzysu migracyjnego, czyli masowego napływu do Europy uchodźców i imigrantów w 2015 r. i kolejnych latach (Kubicki i in., 2017), wojny na Ukrainie oraz znaczących zmian politycznych w samej Polsce (Rajca, 2015). Oprócz tego kryzys migracyjny był w nieetyczny sposób wykorzystywany przez rosnącą propagandę, która używała polityki migracyjnej jako narzędzia do geopolitycznych negocjacji i wewnętrznej walki politycznej. W konsekwencji dyskurs na temat migrantów, zwłaszcza uchodźców, stał się antyimigracyjny (Pietrusińska, 2018), a polityka migracyjna państwa koncentrowała się przede wszystkim na kontestowaniu polityk UE (Adamczyk, 2017), zapewniając bezpieczeństwo poprzez zamykanie granic, zmniejszając skalę imigracji (Ziętek, 2017) i dążąc do asymilacji migrantów przebywających w Polsce. W rezultacie zauważalny jest wzrost nacjonalizmu, ksenofobii, islamofobii, antysemityzmu (Kopiński, Hasen, 2016: Hall, Mikulska-Jolles, 2016; Pasamonik 2017) w dyskursie publicznym. Co więcej, imigrantów i uchodźców, a także ich integrację zaczęto postrzegać przez pryzmat sekurytyzacji - jako zagrożenie dla społeczeństwa (Leszkowicz-Baczyński, 2017; Ziętek, 2017; Pietrusińska, 2018).

Łodziński i Szonert z pewnym optymizmem wskazują, że od 2015 r. polska polityka migracyjna „stała się coraz bardziej uspołeczniona, przechodząc na poziom regionalny i lokalny" (2016: 32). Działania rządu wywołały kontestację nie tylko zinstytucjonalizowanych podmiotów (głównie władz lokalnych i organizacji pozarządowych), ale także zwykłych obywateli, którzy zaczęli aktywnie angażować się w oddolne inicjatywy na rzecz migrantów, takie jak Witamy Uchodźców, Noise for Refugees, Chlebem i Solą, Inicjatywa Obywatelska WITAMY.

W odpowiedzi na rosnącą liczbę migrantów polski rząd podjął w 2019 roku próbę stworzenia nowej krajowej polityki migracyjnej i integracyjnej. Dokument w tym zakresie przygotował Zespół ds. Migracji (2019), jednak spotkał się on $\mathrm{z}$ bardzo negatywnym odbiorem ze strony środowiska akademickiego, organizacji pozarządowych zajmujących się tematyką migracji, jak i samorządów lokalnych. Pomysł został wycofany i Polska nie ma krajowej polityki migracyjnej, a decyzje z tego obszaru podejmowane są ad hoc, w zależności od potrzeb władzy. Wiele samorządów lokalnych zaczęło kwestionować takie podejście rządu i wprowadziło własne rozwiązania w obszarze polityki migracyjnej i integracyjnej. Przykładem tego może być Deklaracja o współpracy między miastami 
polskiej unii metropolitalnej $\mathrm{w}$ dziedzinie migracji podpisana przez prezydentów 12 polskich miast (Warszawy Białegostoku, Gdańska, Poznania, Krakowa, Katowic, Lublina, Łodzi, Szczecina, Wrocławia, Rzeszowa). W deklaracji prezydenci zobowiązali się, wspierani przez Międzynarodową Organizację ds. Migracji i Biuro Wysokiego Komisarza Narodów Zjednoczonych ds. Uchodźców (UNHCR), do współpracy z „administracją rządową, organizacjami pozarządowymi i religijnymi stowarzyszeniami w opracowywaniu i wdrażaniu polskiej polityki migracyjnej opartej na bezpiecznym zarządzaniu migracją”" (Unia Metropolii Polskich, 2017: 1). Efektem tego działania i podobnych akcji na skalę lokalną jest pojawienie się paralelnej polityki migracyjnej. Nie tylko widać wyraźny rozdźwięk pomiędzy tą polityką na szczeblu centralnym i lokalnym, ale także podkreśla się znaczenie lokalności dla procesu integracji migrantów. Ta ostatnia zmiana, wymuszona przez rządową politykę antyimigrancką, otwiera przestrzeń dla pedagogów społecznych, animatorów, edukatorów do współpracy z migrantami w duchu demokracji obywatelskiej, emancypacji, sprawczości, szacunku i lokalności. Zgodnie z tym podejściem władze lokalne biorą na siebie ciężar odpowiedzialności za akulturację migrantów, ich adaptację społeczno-kulturową ${ }^{2}$, integrację̧${ }^{3}$ i inkluzję społecznąa

\footnotetext{
${ }^{1}$ Akulturacja to ,jednokierunkowy i liniowy proces analogiczny do socjalizacji, ale dotyczący przyswajania kultury innej niż ta, w której wychowała się jednostka lub grupa" (Grzymała-Kazłowska, 2008: 40). W ramach tego procesu jednostka zyskuje lub też nie nowe kompetencje językowo-kulturowe oraz orientacje normatywne charakterystyczne dla grupy dominującej (Cieślikowska, 2012).

${ }^{2} \mathrm{~W}$ terminie adaptacja społeczno-kulturowa akcent pada przede wszystkim na przetrwanie (biologiczne, społeczne i kulturowe) jednostki w nowym społeczeństwie. W odróżnieniu od akulturacji, której pożądanym skutkiem jest „poprawne”, tj. zgodne z normami funkcjonowanie w nowym społeczeństwie, adaptacja polega raczej na efektywnym przystosowaniu się do nowych warunków środowiska społeczno-kulturowego, niekoniecznie jednak zgodnych z ogólnymi normami. Adaptacja społeczno-kulturowa służy wypracowaniu jak najefektywniejszego sposobu radzenia sobie w nowej rzeczywistości przy jednoczesnym zaspokajaniu swoich potrzeb i zachowaniu równowagi psychicznej (Pietrusińska, 2012).

${ }^{3}$ Integracja to jedna ze strategii akulturacyjnych skutkująca zarówno pozytywnym wartościowaniem dwukulturowości, przeobrażeniem tożsamości jednostki poprzez dołączenie do istniejących już struktur normatywnych praw, zasad i wartości charakterystycznych dla kultury przyjmującej, jak i nabywaniem kompetencji związanych z dwujęzycznością i dwukulturowością (Berry, 1997). Integracja zachodzi na podstawie długotrwałych, pozytywnych relacji etnicznych i skutkuje na poziomie jednostkowym pojawieniem się poczucia wspólnoty kulturowej z członkami i członkiniami społeczeństwa przyjmującego. Nie należy jednak mylić jej z asymilacją, która oznacza całkowite przyjęcie kultury grupy dominującej jako swojej przy jednoczesnym odrzuceniu całej kultury macierzystej. Termin asymilacja jest często używany w dyskursie antymigracyjnym, ksenofobicznym i wykluczającym (Gapich, 2016).

${ }^{4}$ Inkluzja społeczna to „proces, który zapewnia osobom zagrożonym ubóstwem i wykluczeniem społecznym możliwości i zasoby niezbędne do pełnego uczestnictwa w życiu gospodarczym, społecznym, politycznym i kulturalnym oraz do korzystania ze standardu życia uważanego za nor-
} 


\section{Wyzwania stojace przed pedagogami społecznymi pracującymi z migrantami}

Według oficjalnych danych Urzędu ds. Cudzoziemców w 2019 r. 368085 osób dorosłych i 39909 nieletnich ma ważne dokumenty zezwalające na pobyt w Polsce, a 1293 osoby dorosłe i 973 osoby nieletnie złożyły wnioski o ochronę międzynarodową (migracje.gov.pl). Mimo że liczba dzieci jest prawie dziesięciokrotnie mniejsza niż dorosłych, do pierwszej grupy kieruje się większość projektów edukacyjnych i działań, które obejmują głównie formalny system edukacji. Temat dorosłych migrantów nie jest wystarczająco opisany w polskiej literaturze dotyczącej sposobów integracji i inkluzji związanych $\mathrm{z}$ tą grupą. Jest to rezultatem tego, że dopiero od około pięciu lat, czyli od czasu, gdy polska polityka migracyjna kształtowana jest głównie przez jednostki samorządu terytorialnego, istnieją liczniejsze oferty edukacyjne związane z podnoszeniem kompetencji zawodowych w obszarze inkluzji i integracji dorosłych osób $\mathrm{z}$ doświadczeniem migracji ${ }^{5}$.

Przemiany w środowiskach wychowawczych i w konsekwencji nowe warunki pracy pedagogów społecznych są przede wszystkim zakorzenione w dyskursie proimigranckim (a de facto prouchodźczym) będącym odpowiedzią na narracje antyimigranckie, które pojawiły się w Polsce po 2015 roku. Narracje prouchodźcze budowane są na postawach solidarności i współczucia wobec uchodźców (Kopiński, Hansen, 2016; Pietrusińska, 2018). Niemniej jednak uchodźca jest w nich przedstawiany jako osoba bezradna, poddająca się losowi, w trudnej (dramatycznej) sytuacji życiowej - sytuacji wojennej (opisywanej w kategoriach: tragedii, ucieczki, bombardowania, trudu, niepewności, braku autonomii, poczucia straty). Jednocześnie taka figura retoryczna uchodźcy wytwarza w ludziach z krajów Zachodu poczucie moralnego obowiązku wobec uchodźców. Narracja budowana w ten sposób nakłada w pewnym sensie nakaz wspierania i chronienia marginalizowanych grup społecznych. Europejczycy pojawiają się w tej narracji jako swego rodzaju wybawcy - są bardziej cywilizowani i bardziej kompetentni,

malny w społeczeństwie, w którym żyją. Zapewnia im większy udział w podejmowaniu decyzji, które mają wpływ na ich życie, i dostęp do ich praw podstawowych" (Commission of the European Communities, 2003: 9). O ile integracja zachodzi na poziomie jednostkowym, to inkluzja jest procesem kolektywnym, w ramach którego członkowie i członkinie dwóch lub więcej grup w ramach współpracy i negocjowania wartości, norm oraz sposobów ich ekspresji wytwarzają na forum publicznym nową jakość.

${ }^{5}$ Pomijam tutaj kursy i studia przygotowujące do nauczania języka polskiego jako obcego oraz działania edukacyjne, których celem jest wzrost kompetencji umożliwiających świadczenie wsparcia prawnego. Mam na myśli bardziej holistyczne formy działań, w których mogą odnajdywać się pedagodzy społeczni. 
wiedzą, jak rozwiązywać problemy, i decydują o losie uchodźców przybywających do ich krajów. Sprawia to, że pomoc osobom poszukującym ochrony międzynarodowej oparta jest na asymetrycznej relacji między uchodźcami a społeczeństwem przyjmującym (Pietrusińska, 2020).

Przemoc symboliczna i asymetria relacji są ze sobą powiązane (Farjaudon, Morales, 2012). Widać to wyraźnie na przykładnie stosunków do uchodźców w humanitaryzmie (reżimie humanitarnym), który oparty jest na dwóch zasadach - ochrony i pomocy (Bouju, Ayimpam, 2015). Te dwie zasady nie tylko na poziomie dyskursu, ale także realnych działań organizacji humanitarnych wprowadzają asynchroniczne stosunki pomiędzy nimi a migrantami przymusowymi, w których to ci drudzy są całkowicie zależni od tych pierwszych. Co więcej, w tych relacjach ujawnia się przemoc symboliczna, ale też jak najbardziej realna porównywana przez Marka Duffielda (2004) do foucaultowskiej biopolityki. Jeśli chodzi z kolei o migrantów w ogóle, to muszą oni dostosować się do warunków nowego kraju, zaakceptować jego zasady, prawa, zwyczaje, język, tradycje - różne postrzeganie świata. Ludzie, którzy pracują z migrantami, są pewnego rodzaju odźwiernymi, ale również ich opiekunami, dlatego właśnie od ich decyzji zależy, czego i jak osoby z doświadczeniem migracyjnym będą się uczyć, a także w jaki sposób będzie przebiegać ich akulturacja i adaptacja społeczno-kulturowa. W takiej relacji migranci są raczej biernymi odbiorcami istniejącej rzeczywistości. Co więcej, od modelu relacji międzygrupowych wiodących w społeczeństwie przyjmującym (wielokulturowość, tygiel kulturowy, segregacja, marginalizacja) zależy, czy strategie akulturacyjne poszczególnych cudzoziemców będą w stanie osiągnąć pozytywny efekt w postaci integracji (Berry, 1997).

Przemoc symboliczna jest również widoczna, gdy organizacje pozarządowe organizują różnorodne działania integracyjne i edukacyjne, spotkania, warsztaty i festyny. Podczas tego rodzaju wydarzeń wybrane kultury są prezentowane poprzez narodowe potrawy, stroje, tańce, muzykę i sztukę (np. Wielokulturowe Street Party). Niestety, ten rodzaj działalności jest często nazywany przez migrantów „cepelią" (Diouf, Średziński, 2012: 5). Tego rodzaju działania zdaniem cudzoziemców mogą tworzyć nieprawdziwy komunikat i umacniać stereotypowe i orientalizowane obrazy o migrantach, ich krajach pochodzenia i w rzeczywistości nie integrować migrantów oraz przedstawicieli grupy dominującej, a jedynie wzmacniać między nimi dystans ontologiczny (Walczak, 2006). Inny, przedstawiony poprzez stereotypy i upraszczające dyskursywne motywy, staje się nieznanym, czyli „obcym obiektem do oswojenia" (Walczak, 2006: 134).

Taki dyskurs i działania mogą wzmacniać brak upodmiotowienia i sprawczości cudzoziemców. Może to wynikać także głównie z samej migracji, szczególnie 
w kontekście uchodźców. Stres akulturacyjny - emocjonalna reakcja na zmianę w kulturze pobytu związana $\mathrm{z}$ wieloma stresorami (Berry, 1997) - często powoduje wyuczoną bezradność i wyuczoną zależność, depresję, lęk, niższą samoocenę, problemy z tożsamością i utratę autonomii (Boekestijn, 1988; Telzer, Vazquez, 2009; Gembala, 2010; Kubitsky, 2012; Gebregergis, 2018). Wszystko to zabiera sprawczość osób migrujących. Stają się one zależne od członków społeczeństwa przyjmującego, a także członków poprzednich fal migracyjnych, co czyni ich pasywnymi, posłusznymi i niezaangażowanymi.

Ich głos i zdanie nie są brane pod uwagę. Zgodnie z koncepcją podporządkowanych innych Gayatri Chakravorty Spivak (1988), która obejmuje również migrantów, należy podkreślić, że instytucje i organizacje promigranckie uciszają grupy mniejszościowe. Pomijając ogromny problem nierównych struktur władzy, jednym z problemów jest brak wglądu i zrozumienia dla podporządkowanych innych, zrozumienia, na czym rzeczywiście polegają ich potrzeby, czy chcą być „uratowani”. Mówiąc w imieniu podporządkowanych innych, animatorzy, pracownicy socjalni, edukatorzy i pedagodzy społeczni ignorują kwestię słyszalności, reprezentacji i sprawczości. W ten sposób konsolidują swoją siłę - siłę dominującej grupy - i dalej wyciszają mniejszości. Kiedy migranci milczą, ci, którzy z nimi pracują, często zachowują się (zwykle nieświadomie) w sposób paternalistyczny. Oznacza to również, że dorośli migranci są często traktowani i nauczani tak, jakby byli dziećmi. Do niedawna także wiele organizacji i instytucji pomagających obcokrajowcom uważało ich proces adaptacji społeczno-kulturowej za zakończony, jakby cudzoziemka lub cudzoziemiec mogli komunikować się w języku polskim i byli w stanie funkcjonować w codziennej rzeczywistości. W związku z tym migranci nie byli przygotowani do pełnego i aktywnego uczestnictwa w życiu społecznym, np. zabrania głosu w debacie publicznej na temat interesów ich diaspory lub zwalczania dyskryminacji i wykluczenia.

\section{Rola pedagogów społecznych w społeczeństwie wielokulturowym}

W artykule z 2012 roku Agnieszka Naumiuk opisała, w odniesieniu do przemian społecznych w baumanowskiej płynnej nowoczesności, nowe zadania, jakie stoją przed pedagogami społecznymi, których określiła mianem animatorów zmian w środowisku. Chociaż postulowała, aby nadal podążać za głosem Heleny Radlińskiej i „przetwarzać dzień dzisiejszy siłami człowieka w imię ideałów” (Naumiuk, 2012: 42), jednocześnie przedstawiła propozycje rozszerzenia roli pedago- 
gów społecznych, które w 2020 roku stały się jednymi z wiodących kierunków pracy w tej grupie. Odnosząc się do tego katalogu funkcji pedagogów społecznych, postaram się wykazać, na jakie trudności narażeni są oni w kontekście pracy z migrantami, a jednocześnie chciałabym pokazać własne propozycje przezwyciężenia tych trudności.

Jednym z pierwszych postulatów Naumiuk jest budowanie partnerskiego podejścia w relacji między jednostkami (np. migrantami) a pedagogami społecznymi określanymi tu mianem „strażników podmiotowości” (Naumiuk, 2012: 42). Hegemonia dyskursu proimigranckiego (Pietrusińska, 2020), który uprzedmiotawia migrantów i odbiera im sprawczość oraz decyzyjność, sprawia jednak, że również pedagogom społecznym może być trudno uwolnić się od swojej roli „wszystkowiedzących osób niosących pomoc i opiekę", tym bardziej że rola ta pozwala w dużo szybszy sposób osiągnąć „poprawny” efekt akulturacji. Jednocześnie takie działania zwalniają migrantów i migrantki z odpowiedzialności za swój proces akulturacji, integracji również w późniejszych etapach inkluzji i budują wyuczoną bezradność.

Wyjściem z tego narracyjnego klinczu może być dawanie przestrzeni do działań upodmiotawiających już od pierwszego spotkania, np. pozwolenie osobie z doświadczeniem migracyjnym, żeby wybrała pedagoga społecznego, z którym chciałaby pracować. Takie małe akty emancypacyjne, do których nie są potrzebne rozwinięte kompetencje językowe i kulturowe, stanowić mogą punkt wyjścia w długim procesie nabywania sprawczości i decyzyjności.

Naumiuk pisze o pedagogu społecznym również jako o „strażniku [...] aktywności nastawionej na kierowanie własnym życiem” (2012: 42). Zgodnie z tą myślą pedagodzy społeczni są osobami towarzyszącymi migrantom w samorozwoju od początku akulturacji aż do inkluzji, w sytuacji, kiedy dyskurs publiczny utrwala asymetryczność jednych i drugich oraz nakłada na pedagogów społecznych odpowiedzialność za „poprawne” przeprowadzenie osób z doświadczeniem migracyjnym przez proces akulturacji. $\mathrm{W}$ tak rozumianej relacji nie ma przestrzeni dla sprawczości imigrantów i pozwolenia im na podejmowanie decyzji w sprawie ich własnej adaptacji społeczno-kulturowej, integracji czy inkluzji.

Aby uciec z tej „dyskursywnej pułapki”, pedagodzy społeczni mogą postrzegać siebie raczej jako przewodników niż strażników. Przedstawiając to w sposób metaforyczny, można powiedzieć, że pedagodzy społeczni, podobnie jak przewodnicy, znają cel akulturacji i integracji, ale zamiast trzymać się jedynej drogi prowadzącej do jego osiągnięcia, jak robią to strażnicy, pozwalają migrantom odkrywać na ich indywidualny sposób różne ścieżki, które prowadzą do integracji i inkluzji oraz wskazują możliwe wyzwania i przeszkody w podróży ku nim. 
Kolejnym ważnym z perspektywy tego artykułu postulatem Naumiuk jest połączenie przez pedagoga społecznego trzech form pracy $-\mathrm{z}$ jednostką, z grupą i ze społecznością lokalną (Naumiuk, 2012). Ma to między innymi na celu ułatwianie i animowanie międzykulturowych relacji między migrantami a członkami społeczeństwa przyjmującego. Zadaniem pedagogów jest oswajanie migrantów i „gospodarzy” z „obcością" i „innością”, przedstawienie ich sobie, co w efekcie końcowym prowadzić ma do inkluzji i powstania nowej jakości w relacjach społecznych. Zgodnie z tym podejściem nie tylko migranci, ale także członkowie społeczeństwa przyjmującego uczą się od siebie i poprzez te kontakty zwiększają swoje kompetencje międzykulturowe oraz przebudowują społeczności, w których żyją. Trudno jednak facylitować takie kontakty, jeśli jedna za stron pozostaje „niema” i „podporządkowana" - zarówno ze względu na brak wiary we własne siły i możliwości po stronie migrantów, jak i orientalizujące oraz stereotypizujące wyobrażenia na ich temat po stronie społeczeństwa dominującego.

Takie działania są możliwe między innymi wtedy, gdy istnieją przestrzenie, w których migranci mogą czuć się „słyszani” i „poważani”. Centrum Wielokulturowe w Warszawie lub Europejskie Centrum Solidarności w Gdańsku to dobre przykłady takich miejsc. Również Miejsca Aktywności Lokalnej zapewniają przestrzeń, w której migranci i „gospodarze” mogą spotykać się na co dzień i integrować się, przebywając razem. Na przykład w Centrum Wielokulturowym migranci angażują się, dzieląc się swoją wiedzą i umiejętnościami podczas organizowanych przez siebie wydarzeń i działań (np. rozmowy po angielsku z Bom). Pełniąc funkcję „nauczycieli”, gospodarze obcokrajowcy wzmacniają swoje umiejętności językowe, ale także powiększają kapitał społeczny. Ponieważ to właśnie aktywna rola migrantów jest konieczna i kluczowa, pedagodzy społeczni powinni być współtwórcami i współprowadzącymi takie miejsca.

Innym sposobem na wyjście z „ciszy” może być facylitowanie konfliktów przez pedagogów społecznych. Konflikt może mieć znaczący i pozytywny wpływ na zmianę społeczną, jeśli jest właściwie moderowany, a siły grup biorących w nim udział są balansowane przez czynnik zewnętrzny, jakim może być właśnie pedagog społeczny. Jak twierdzi Kund Illeris (2006), uczenie się jest najskuteczniejsze w sytuacjach konfliktu zewnętrznego lub wewnętrznego, rozumianego również jako dysonans poznawczy. Jednostka musi wtedy wyjść poza swoje obecne wzorce działania i myślenia. Proces ten może odbywać się na dwa sposoby: podczas długoterminowej adaptacji lub podczas krótszych intensywnych działań. W wyniku krytycznej refleksji następuje proces uczenia się, a zatem zmiany zachodzą w obrębie samego ucznia i otaczającego go środowiska. Konflikt jako sytuacja krytycz- 
na może zatem pozwalać na uwolnienie pokładów podmiotowości i sprawczości drzemiących w „niemych” migrantkach i migrantach.

Naumiuk w swoim artykule pisze także o refleksyjności jako o ważnej kompetencji pedagogów społecznych. Pozwala ona na systematyczne dokonywanie samooceny swoich działań, w tym między innymi ciągłego rozwijania i dostosowywania kompetencji zawodowych do potrzeb jednostek i grup, z którymi się pracuje (Szymczak, 2009). Z własnego długoletniego doświadczenia w pracy z migrantami i na rzecz migrantów wiem też, że niewielu praktyków pracujących z dorosłymi imigrantami i uchodźcami ma kompetencje andragogiczne czy międzykulturowe. Wynika to z tego, że przez wiele lat dorośli migranci rzadko bywali grupą docelową działań włączających, co skutkowało brakiem zapotrzebowania na specjalistów o takich kompetencjach.

Dlatego też przy zmieniającym się na obecną chwilę podejściu do pracy z migrantami (Pietrusińska, 2019) warto zdobyć wiedzę andragogiczną i kompetencje międzykulturowe (Bandach, 2018). Obecnie znacznie częściej prowadzi się warsztaty czy kursy wzmacniające wiedzę, umiejętności i postawy związane z wielokulturowością i kontaktem międzykulturowym niż działania wzmacniające kompetencje związane z uczeniem (się) osób dorosłych. Właśnie im chciałabym poświęcić fragment tego artykułu.

Omawiając andragogiczne konsekwencje migracji, warto zauważyć, że dorośli uczą się inaczej niż dzieci i młodzież (Kazimierska i in., 2014). Przede wszystkim dorosłych nie można zmuszać do nauki - musi to być ich autonomiczna decyzja. Po drugie, zwykle dość jasno określają oni cele swojego procesu uczenia się i chcą widzieć adekwatność zdobytej wiedzy, umiejętności lub zmianę postaw wobec swoich potrzeb. Po trzecie, dorośli opierają swoją naukę na własnych doświadczeniach, wiedzy i umiejętnościach, odnoszą się do nich podczas procesu edukacji, dlatego podczas pracy z dorosłymi migrantami warto odwoływać się do źródeł andragogicznych. Wzmocnienie całych społeczności (nie tylko samych migrantów) można osiągnąć poprzez zastosowanie inspiracji andragogicznych, takich jak: uczenie transformatywne (Mezirow, 2003), uczenie się przez doświadczenie (Jarvis, 2006, 2009), sytuacyjne uczenie się (Lave, Wenger, 1991), uczenie się przez zaangażowanie (Eyler, Giles, 1999), uczenie biograficzne (Alheit, 2009) oparte na tradycjach edukacji społeczności lokalnej (Johnson, 2003) i edukacji radykalnej (Brookfield, 2005). Jednocześnie podejścia te mogą być również z powodzeniem stosowane przez edukatorów w budowaniu wielokulturowych, spójnych społeczności lokalnych opartych na demokratycznych zasadach. 


\section{Podsumowanie}

Pedagodzy społeczni w Polsce pracujący z migrantami stają przed różnymi wyzwaniami ze względu na złożoną mieszankę zwiększonego napływu migrantów (zwłaszcza z Ukrainy), politykę antyimigrancką w dyskursie rządowym, poziomowym i proimigranckim, który wprowadza nierówności, kształtuje migrantów biernych, uprzedmiotowionych i bez sprawczości. Dodatkowo kompetencje międzykulturowe i andragogiczne wielu pedagogów społecznych nie są wystarczające, by podołać tym wyzwaniom.

Wszystko to tworzy złożony kontekst społeczny, w którym muszą oni na nowo zdefiniować własne role zawodowe. Napotykają liczne trudności, takie jak struktura relacji władzy między nimi a osobami z doświadczeniem migracyjnym „niemymi, podporządkowanymi” migrantami, którzy stają się tacy ze względu na stereotypowe i neokolonialne figury i toposy proimigracyjnego dyskursu, symboliczną przemoc wywołaną przez reżim humanitarny.

Istnieje jednak szansa, że mogą sprostać tym wyzwaniom i pokonać owe trudności poprzez świadome przekształcenie swoich zadań i ról jako pedagogów społecznych. Zamiast pozostać opiekunami akulturacji, mogą stać się „stróżami podmiotowości i działań skoncentrowanych na zarządzaniu własnym życiem”, prowadzących do integracji i inkluzji społecznej.

\section{Bibliografia}

Adamczyk A. (2017), Kryzys migracyjny w Europie a polska polityka imigracyjna, „Studia Migracyjne - Przegląd Polonijny", 163, s. 307-331.

Alheit P. (2009), Całożyciowe uczenie się i kapitał społeczny, „Teraźniejszość - Człowiek - Edukacja. Kwartalnik Myśli Społeczno-Pedagogicznej”, nr 4 (48), s. 7-23.

Bandach M. (2018), Kompetencje do komunikacji międzykulturowej osób realizujących zadania w obszarze pracysocjalnej. Praca doktorska, https://repozytorium.uwb.edu.pl/jspui/bitstream/11320/7591/1/M_ Bandach_Kompetencje_do_komunikacji_miedzykulturowej.pdf [dostęp: 15.08.2019].

Berry J.W. (1997), Immigration, Acculturation, and Adaptation, „Applied Psychology”, no. 46 (1), pp. 5-34.

Boekestijn C. (1988), Intercultural migration and the development of personal identity: The dilemma between identity maintenance and cultural adaptation, „International Journal of Intercultural Relations", 12 (2), pp. 83-105.

Bouju J., Ayimpam S. (2015), Ethnocentrism and partnership: the symbolic violence of humanitarian aid, „Fonds Croix-Rouge française. Les Papiers du Fonds”, no. 1, pp. 1-15.

Brookfield S. (2005), The Power of Critical Theory for Adult Learning and Teaching, New York.

Cieślikowska D. (2012), Psychologiczne i społeczne konsekwencje wyjazdu do innego kraju, w: Od migracji do integracji, red. A. Chmielecka, Warszawa, s. 37-65. 
Commission of the European Communities (2003), Joint report on social inclusion summarizing the results of the examination of the National Action Plans for Social Inclusion (2003-2005), http:// eur-lex.europa.eu/legal-content/EN/TXT/?uri=celex:52003DC0773 [dostęp: 12.11.2020].

Czakon-Tralski D., Kłóska I. (2018), Migracje. Polska na tle Europy, „Zeszyty Naukowe Politechniki Śląskiej”, 126, s. 65-77.

Diouf M., Średziński P. (2012), Integracja przez kulturę i wzajemne poznanie, Warszawa.

Duffield M. (2004), Carry on killing: global governance, humanitarianism and terror, „DIIS Working Paper", 23.

Eyler J., Giles D.E. (1999), Where's the learning in service-learning?, San Francisco.

Farjaudon A.L., Morales J. (2012), In search of consensus: The role of accounting in the definition and reproduction of dominant interests. Referral XXIème conférence de l'AIMS, Lille, France.

Gapich M. (2016), Wielokulturowość i jej wrogowie, „Liberte!”, https://liberte.pl/wielokulturowosci-jej-wrogowie/ [dostęp: 13.11.2020].

Gebregergis W. (2018), Major Causes of Acculturative Stress and Their Relations with Sociodemographic Factors and Depression among International Students, „Open Journal of Social Sciences", 6, pp. 68-87.

Gembala A. (2010), Kilka refleksji na temat współczesnego rozumienia zjawiska migracji, http://www. zuviel.net/content/view/81/38/ [dostęp: 20.08.2019].

Gmaj K. (2012), Wprowadzenie w zagadnienia migracji i integracji, w: Od migracji do integracji, red. A. Chmielecka, Warszawa, s. 11-36.

Grzymała-Kazłowska A. (2013), Od tożsamości i integracji do społecznego zakotwiczenia - propozycja nowej koncepcji teoretycznej, http://www.migracje.uw.edu.pl/wp-content/uploads/2016/10/ WP_64122_2.pdf [dostęp: 01.01.2020].

Hadzińska-Wyrobek A. (2011), Wizerunek uchodźcy w polskiej prasie po 1990 r. oraz rola mediów w kształtowaniu stereotypu uciekiniera, „Media - Kultura - Społeczeństwo”, nr 1, s. 113-125.

Hall D., Mikulska-Jolles A. (2016), Uprzedzenia, strach czy niewiedza? Młodzi Polacy o powodach niechęci do przyjmowania uchodźców, „Analizy. Raporty. Ekspertyzy”, nr 1.

Ileris K. (2006), Trzy wymiary uczenia się: poznawcze, emocjonalne i społeczne ramy współczesnej teorii uczenia się, tłum. A. Jurgiel i in., Wrocław.

Januszewska E., Markowska-Manista U. (2017), Dziecko „inne” kulturowo w Polsce. Z badań nad edukacją szkolną, Warszawa.

Jarvis P. (2006), Towards a Comprehensive Theory of Human Learning, London-New York.

Jarvis P. (2009), Learning to be a Person in Society, London-New York.

Johnson R. (2003), Adult Learning and Citizenship: Clearing the Ground, w: Adult learning, citizenship and community learning, eds. P. Coare, R. Johnson, Oxford.

Kazimierska I., Lachowicz I., Piotrowska L. (2014), Uczenie się dorosłych - cykl Kobla, Warszawa.

Kropiński M., Hasen K. (2016), Jakie skojarzenia ze słowem „uchodźca” maja Polacy?, Warszawa.

Kubicki P., Pawlak M., Mica A., Horolets A. (2017), Wyjście z cienia. Polityka uchodźcza w sytuacji kryzysu, „Polityka Społeczna”, 9 (522), s. 22-28.

Kubitsky J. (2012), Psychologia migracji, Warszawa.

Lave J., Wengera E. (1991), Situated Learning: Legitimate Peripheral Participation, Cambridge.

Leszkowicz-Baczyński J. (2017), Koncepcja lęku społecznego jako składnik analizy uwarunkowań postrzegania imigrantów przez Polaków w świetle kryzysu migracyjnego w Europie, w: Między tolerancją a niechęcią. Polityka współczesnych państw europejskich wobec migrantów i mniejszości, red. A. Adamczyk, A. Sakson, C. Trosiak, Poznań, s. 315-326. 
Łazor J. (2016), Polska polityka imigracyjna wobec cudzoziemców 1918-2012, w: Polityka migracyjna: historia i współczesne wyzwania, red. K. Górak-Sosnowska, J. Łazor, Warszawa, s. 103-120.

Łodziński S., Szornet M. (2016), „Niepolityczna polityka?” Kształtowanie się polityki migracyjnej w Polsce w latach 1989-2016, „CMR Working Papers”, 90/148.

Mezirow J. (2003), Transformative Learning as Discourse, „Journal of Transformative Education”, vol. 1 , no. 1, pp. 58-63.

Naumiuk A. (2012), Pedagog społeczny - animator zmiany w środowisku, „Pedagogika Społeczna”, $4 / 12$, s. $41-56$.

Pasamonik B. (2017), „Malowanie strasznego diabła” - metamorfoza obrazu uchodźcy w Polsce, w: Kryzys migracyjny. Perspektywa społeczno-kulturowa, t. 1, red. B. Pasamonik, U. Markowska-Manista, Warszawa, s. 15-45.

Pietrusińska M.J. (2018), Inny-ja czy Obcy-potrzebujacy. Wizerunki uchodźcy w prouchodźczych działaniach edukacyjnych, „Czas Kultury”, 3, s. 150-158.

Pietrusińska M.J. (2019), Edukacja dorostych jako element inkluzji migrantów - propozycja zmiany podejścia, „Edukacja”, 1, s. 42-53.

Pietrusińska M.J. (2020), Reprezentacje uchodźców w polskiej literaturze dziecięcej - przykład dyskursu prouchodźczego, „Studia Migracyjne - Przegląd Polonijny”, nr 1 (175), s. 47-66.

Rajca L. (2015), Integracja imigrantów w Polsce $w$ dobie kryzysu migracyjno-uchodźczego, „Chorzowskie Studia Polityczne", nr 10, s. 183-202.

Spivak G.C. (1988), Can the subaltern speak?, Basingstoke.

Szymczak. J. (2009), Bycie (stawanie się) refleksyjnym nauczycielem. Perspektywa socjokulturowa, „Forum Dydaktyczne”, 5-6, s. 50-59.

Telzer E.H., Vazquez Garcia H.A. (2009), Skin color and self-perceptions of immigrant and US-born Latinas: The moderating role of racial socialization and ethnic identity, „Hispanic Journal of Behavioral Sciences", 31 (3), pp. 357-374.

Unia Metropolii Polskich (2017), Deklaracja o współpracy między miastami polskiej unii metropolitalnej $w$ dziedzinie migracji, https://www.metropolie.pl/wp-content/uploads/2017/07/Tekst-deklaracji-UMP-z-30-czerwca-2017.pdf [dostęp: 20.08.2019].

Walczak A. (2006), Koncepcja rozumienia Innego w kategorii spotkania, w: Pedagogika społeczna. Podręcznik akademicki, t. 1, red. E. Marynowicz-Hetka, Warszawa, s. 130-139.

Zespół ds. Migracji (2019), Polityka migracyjna Polski, Warszawa, https://interwencjaprawna.pl/wp-content/uploads/2019/06/Polityka-migracyjna-Polski-wersja-ostateczna.pdf [dostęp: 09.08.2019].

Ziętek A. (2017), Sekurytyzacja migracji w bezpieczeństwie kulturowym, „Teka Komisji Politologii i Stosunków Międzynarodowych", 12/3, s. 23-42. 